\title{
Electrocardiographic evaluation and serum cardiac troponin I levels in anemic dogs with blood parasitosis
}

\author{
Avaliação eletrocardiográfica e níveis séricos de troponina I \\ cardíaca em cães anêmicos com hemoparasitose
}

\author{
Tatiana Champion ${ }^{1 *}$; Cristiane Francoy ${ }^{2}$; Glaucia Bueno Pereira Neto \\ Aparecido Antônio Camacho ${ }^{4}$
}

\begin{abstract}
Blood parasitosis is a frequent cause of anemia and myocarditis in dogs. Because anemia can trigger hypoxia or hemodynamic disturbances and myocarditis secondary to blood parasitosis can develop arrhythmias, electrocardiogram changes and increased levels of cardiac biomarkers, such as cardiac troponin I, are expected in dogs with blood parasitosis. Thus, this study aimed to investigate the electrocardiographic characteristics and the relationship to troponin I levels in anemic dogs with blood parasitosis. Twenty-eight dogs with blood parasitosis (seropositive for Ehrlichia canis/ Babesia canis) and varying levels of anemia were evaluated. Dogs with very severe anemia (hematocrit below $13 \%$ ) showed significant increases in heart rate when compared to dogs with severe, moderate or mild anemia. There was a predominance of respiratory sinus arrhythmia in dogs with mild, moderate and severe anemia and a high prevalence of sinus rhythm in dogs with very severe anemia, which showed a decrease in parasympathetic activity in this group. In all of the groups, electrocardiographic changes were detected showing compatibility with left and right atrial and left ventricular enlargement. Dogs with very severe anemia had a longer $\mathrm{P}$ wave duration. All groups of anemic dogs showed increased T-wave amplitude, suggestive of myocardial hypoxia. However, only the groups with moderate and severe anemia presented ST segment disturbances. Despite the lack of a correlation between the electrocardiographic changes suggestive of myocardial hypoxia and troponin I, there was a negative correlation $(r=-0.95, p=0.05)$ between hemoglobin levels and increased serum troponin. These data indicate that anemic dogs with blood parasitosis may have electrocardiographic changes suggestive of atrioventricular overload or hemodynamic disturbances, such as increased heart rate. Moreover, the negative correlation between hemoglobin and serum levels of troponin I may imply that dogs with severe and very severe anemia are at a higher risk for myocardial injury.
\end{abstract}

Key words: Cardiac biomarker, electrocardiogram; hematocrit, myocardial hypoxia

\section{Resumo}

Hemoparasitoses são causas frequentes de anemia e miocardite em cães. Em virtude da anemia poder provocar distúrbios hemodinâmicos relacionados à hipóxia e da miocardite secundária à hemoparasitose causar arritmias cardíacas, esperam-se alterações eletrocardiográficas e aumento dos níveis de

\footnotetext{
${ }^{1}$ Prof. of Small Animal Internal Medicine, University of Vila Velha, Vila Velha, ES, Brazil. E-mail: tatiana.champion@gmail.com

${ }^{2}$ Undergraduate student in Veterinary Medicine sponsored by FAPESP, São Paulo State University, campus of Jaboticabal, Jaboticabal, SP, Brazil. E-mail: cfrancoy@uol.com.br

${ }^{3}$ Prof. of Small Animal Internal Medicine, University of Brasilia, Brasília, DF, Brazil. E-mail: bueno.glaucia@gmail.com

${ }^{4}$ Full Prof. of Small Animal Internal Medicine, São Paulo State University campus of Jaboticabal, Jaboticabal, SP, Brazil. E-mail: camacho@fcav.unesp.br

* Author for correspondence
} 
biomarcadores cardíacos como troponina I cardíaca em cães com hemoparasitose. Por conseguinte, este estudo teve como objetivo investigar as características eletrocardiográficas de cães anêmicos por hemoparasitose e a relação da anemia com alterações eletrocardiográficas e aumento da troponina I cardíaca. Para tanto, foram avaliados vinte e oito cães com hemoparasitose, sorologicamente positivos para Ehrlichia canis/ Babesia canis, com diferentes níveis de anemia. Cães com anemia muito grave (hematócrito abaixo de 13\%) apresentaram aumentos significativos da frequência cardíaca, comparados aos cães com anemia grave, moderada ou leve. Houve predomínio de arritmia sinusal respiratória em cães com anemia leve, moderada e grave e alta ocorrência de ritmo sinusal em cães com anemia muito grave, demonstrando diminuição do tônus parassimpático neste grupo. Em todos os grupos, foram detectadas alterações eletrocardiográficas sugestivas de sobrecarga ventricular e atrial esquerda, no entanto, cães com anemia muito grave, tiveram maiores durações de ondas P. Em todos os grupos de cães anêmicos, houve aumento da amplitude da onda $T$, sugestiva de hipóxia do miocárdio. No entanto, apenas os grupos com anemia moderada e grave apresentaram distúrbios do segmento ST. Apesar da falta de correlação entre as alterações eletrocardiográficas sugestivas de hipóxia miocárdica e os níveis de troponina I cardíacas, houve correlação negativa $(\mathrm{r}=-0,95, \mathrm{p}=0,05)$ entre os níveis de hemoglobina e o aumento da troponina sérica. Estes dados permitem inferir que cães anêmicos em decorrência de hemoparasitoses podem apresentar alterações eletrocardiográficas sugestivas de sobrecarga atrioventricular ou distúrbios hemodinâmicos, como aumento da frequência cardíaca. Ademais, a correlação negativa entre hemoglobina e os níveis séricos de troponina I cardíaca podem implicar em maior risco de lesão miocárdica em cães com anemia mais graves.

Palavras-chave: Biomarcadores cardíacos, eletrocardiograma, hematócrito, hipóxia do miocárdio

\section{Introduction}

Anemia is defined as a reduction in the number of erythrocytes and/or a subnormal concentration of hemoglobin per unit volume of blood. The decrease in red cell mass results in reduced oxygen transport and may lead to tissue hypoxia and hemodynamic and non-hemodynamic compensatory events (JONES; HUNT; KING, 2000; CHAMPION; PEREIRA NETO; CAMACHO, 2011). Examples of non-hemodynamic events include an increase in erythropoietin production and a decrease in the affinity of hemoglobin for oxygen (METIVIER et al., 2000). Hemodynamic events, in turn, are related to increased sympathetic activity with consequent increases in cardiac output and to a decrease in systemic vascular resistance due to arterial vasodilation and reduced viscosity (AIRD, 2000; METIVIER et al., 2000).

The cardiac effect of anemia can be explained by the increased metabolic demand of the heart that may exceed its supply of oxygen, leading to hypoxia and myocardial infarction as described in humans with anemia (PORTMAN; STANDAERT; NING, 1995; SZACHNIEWICZ et al., 2003). The hemodynamic effects of anemia can be related to cardiac decompensation in patients with heart failure (HORWICH et al., 2002; KOMAJDA, 2004).

Furthermore, hemodynamic changes secondary to chronic anemia may result in cardiac remodeling because chronic hypoxia causes structural alterations in the cardiac myocyte and activation of other inflammatory systems that worsen heart failure (HORWICH et al., 2002).

There are many causes of anemia in dogs, and the severity can be classified by magnitude, time of evolution and cardiopulmonary adaptations (AIRD, 2000). Ehrlichiosis and babesiosis are frequent causes of anemia and may worsen heart function due to possible promotion of myocardial injury, such as myocarditis and the subsequent development of arrhythmias (LOBETTI; DVIR; PEARSON, 2002; LOBETTI, 2005; DINIZ et al., 2008).

The electrocardiogram is a useful test for the diagnosis of arrhythmias, but it can also be used to evaluate signs of cardiac chambers enlargement and disorders related to myocardial hypoxia (TILLEY, 1995). Furthermore, the cardiac biomarkers are being used in various clinical situations to assess the 
degree of myocardial injury in heart disease in several clinical situations in which myocardial lesions can be related to non-cardiac injuries and anemia as babesiosis (LOBETTI; DVIR; PEARSON, 2002; LOBETTI, 2005) ehrlichiosis (DINIZ et al., 2008) and immune-mediated hemolytic anemia (GOW et al., 2011). Higher serum concentrations of cardiac troponin I in dogs with primary hemolytic anemia than hospitalized ill dogs or healthy dogs revealed that anemia can promote subclinical myocyte damage (GOW et al., 2011).

Because of the possibility of electrocardiographic changes resulting from hemodynamic dysfunction in conditions such as anemia and the possibility of cardiac injury caused by hemoparasitosis, this study aimed to evaluate the electrocardiographic parameters and determinate cardiac troponin I levels in anemic dogs due to natural infection by Erlichia canis and/or Babesia canis.

\section{Material and Methods}

\section{Animals}

Twenty-eight dogs without preexisting heart disease and with anemia due to ehrlichiosis and/ or canine babesiosis were placed into four groups according to the severity of anemia. The groups were classified as mild, moderate, severe and very severe anemia, represented by a hematocrit ranging from 30 to $35 \%(n=7), 20$ to $29 \%(n=7), 13$ to $19 \%$ $(n=7)$ and below $13 \%(n=7)$, respectively. The control group consisted of seven healthy dogs with a negative serology for ehrlichiosis and babesiosis. All animals of each group underwent measurements of serum troponin I levels, blood count, an electrocardiogram and a Doppler echocardiogram.

Anemic dogs were $6.43 \pm 3.83$ years old, weighed $10.45 \pm 7.76 \mathrm{~kg}$ and included 14 males and 14 females. The study included 18 mongrel dogs, six poodles, one pinscher, one boxer, one beagle and one American pit bull. The dogs in the control group were $5.99 \pm 2.91$ years old, weighed $11.56 \pm 6.31$ $\mathrm{kg}$, and included five females and two males, of which three were Mongrel dogs, two were poodles and two were beagles.

\section{Hematologic examinations}

Blood samples were collected by jugular venipuncture for the attainment of complete blood counts. The global count of erythrocytes, leukocytes and platelets, the hemoglobin levels and the packed cell volume average were determined by automated cell counts (ACT-8 Coulter ${ }^{\circledR}-$ Miami - EUA), and the differential leukocyte counts were made in blood smears stained with Rosenfeld and examined by microscopy optics (Microscope Nikon ${ }^{\circledR}$ Eclipse - E 200 Tokyo - Japan). The serological diagnosis of ehrlichiosis and babesiosis was performed by indirect immunofluorescent reaction (RIFI) to detect antibodies against Babesia canis and Erlichia canis, where the samples with titers above 1:20 for E. canis and 1:40 for B. canis were considered positive. Moreover, the determination of cardiac troponin I levels was performed by an automated quantitative method (VIDAS ${ }^{\circledR}$ - Troponin I Ultra - Biomeriéux Marcy-l'Etoile - France) with the ELFA technique (Enzyme-Linked Fluorescent Assay), and the lower limit for the dosage was $0.01 \mathrm{mg} / \mathrm{L}$.

\section{Electrocardiogram}

A six-lead computerized electro-cardiogram (ECG-PC - TEB - São Paulo, Brazil) was used for electrocardiography recording. The dogs were positioned in right lateral recumbence, and the electrode clips were attached to the animals' skin in the standard positions as described by Tilley (1992). The paper speed was $50 \mathrm{~mm} / \mathrm{sec}$, and the electrocardiogram was standardized at $1 \mathrm{mV}=1 \mathrm{~cm}$. The electrocardiogram analysis was obtained from lead II. We measured the following parameters: duration of $\mathrm{P}$ wave (Pms), $\mathrm{P}$ wave amplitude (PmV), duration of PR interval (PRms), duration of QRS complex (QRSms), R wave amplitude (RmV), 
duration of QT interval (QTms), ST segment amplitude (ST), T wave amplitude (T), mean electrical axis, heart rate (HR) and heart rhythm.

\section{Statistical analysis}

The statistical analysis was performed using statistical software (Statistical software MINITAB 15.1 State College, USA). The distribution pattern of normality was assessed by Kolmogorov-Smirnov test. Parametric variables were analyzed using analysis of variance (ANOVA) followed by a Tukey's test (electrocardiographic parameters). The Pearson correlation test was used to compare hemoglobin levels and electrocardiographic parameters, and the chi-square test was used to analyze categorical variables (troponin elevation and degree of anemia) using a $5 \%$ level of significance.

\section{Results}

The mean values and the standard deviations of the total erythrocyte count, the hemoglobin concentration and the hematocrit of the control group and the anemic groups, divided according to the severity of anemia, are shown in Table 1.

Table 1. Mean values \pm SD of erythrocytes, hemoglobin and hematocrit in the control group, and the mild, moderate, severe and very severe anemia groups.

\begin{tabular}{cccc}
\hline & Erythrocytes x10 $^{\mathbf{3}}$ & Hemoglobin $\mathbf{( g / d L )}$ & Hematocrit (\%) \\
\hline Control Group & $6337.14 \pm 662.14$ & $14.97 \pm 1.75$ & $46.09 \pm 5.64$ \\
Mild anemia & $4965.71 \pm 162.36$ & $11.81 \pm 1.35$ & $33.37 \pm 1.59$ \\
Moderate anemia & $4040.00 \pm 415.57$ & $9.33 \pm 1.29$ & $27.09 \pm 2.97$ \\
Severe anemia & $2444.29 \pm 452.62$ & $5.76 \pm 0.73$ & $17.23 \pm 1.34$ \\
Very severe anemia & $1502.86 \pm 410.96$ & $3.36 \pm 0.44$ & $10.21 \pm 1.68$ \\
\hline
\end{tabular}

Source: Elaboration of the authors.

Only three out of the 28 anemic dogs showed no evidence of concurrently possessing antiErlichia and anti-Babesia antibodies. Of these dogs, two dogs from the group with severe anemia had positive serology only for Erlichia canis, and one dog from the group with very severe anemia had positive serology only for Babesia canis.

Pertaining to cardiac rhythm, there was a predominance of respiratory sinus arrhythmia in groups with mild and moderate anemia, and in both groups, $87.71 \%$ of the dogs presented this rhythm. The group with severe anemia revealed a predominance of sinus arrhythmia, involving
$57.14 \%$ of the dogs. In the group with very severe anemia, $42.86 \%$ of the dogs showed sinus arrhythmia. The second-most common rhythm was sinus rhythm, appearing in $12.29 \%$ of the dogs in groups with mild and moderate anemia and $42.86 \%$ of the dogs in groups with severe and very severe anemia. Only one dog in the group with severe anemia showed junctional rhythm.

The heart rate in dogs with very severe anemia was higher than the other groups, and there were no significant differences between groups with mild, moderate and severe anemia. The heart rate values and other electrocardiographic parameters are shown in Table 2. 
Table 2. Mean values and standard deviations of electrocardiographic parameters in dogs $(n=28)$ with different degrees of anemia caused by Ehrlichia canis and Babesia canis infections in relation to the control group.

\begin{tabular}{cccccc}
\hline & & \multicolumn{4}{c}{ Anemia } \\
\cline { 3 - 6 } & $\begin{array}{c}\text { Control Group } \\
(\mathbf{n}=7)\end{array}$ & $\begin{array}{c}\text { Mild } \\
(\mathbf{n}=7)\end{array}$ & $\begin{array}{c}\text { Moderate } \\
(\mathbf{n}=7)\end{array}$ & $\begin{array}{c}\text { Severe } \\
(\mathbf{n}=7)\end{array}$ & $\begin{array}{c}\text { Very severe } \\
(\mathbf{n}=7)\end{array}$ \\
\hline P $(\mathrm{ms})$ & $41.86 \pm 2.54^{\mathrm{a}}$ & $45.57 \pm 4.61^{\mathrm{a}}$ & $44.28 \pm 6.13^{\mathrm{a}}$ & $44.72 \pm 5.62^{\mathrm{a}}$ & $55.71 \pm 6.72^{\mathrm{b}}$ \\
$\mathrm{P}(\mathrm{mV})$ & $0.20 \pm 0.02^{\mathrm{a}}$ & $0.23 \pm 0.10^{\mathrm{a}}$ & $0.15 \pm 0.06^{\mathrm{a}}$ & $0.18 \pm 0.09^{\mathrm{a}}$ & $0.19 \pm 0.05^{\mathrm{a}}$ \\
PR (ms) & $90.43 \pm 10.5^{\mathrm{a}}$ & $109.14 \pm 6.4^{\mathrm{a}}$ & $95.71 \pm 20.1^{\mathrm{a}}$ & $90.43 \pm 6.6^{\mathrm{a}}$ & $87.00 \pm 23.1^{\mathrm{a}}$ \\
QRS (ms) & $54.57 \pm 4.61^{\mathrm{a}}$ & $56.71 \pm 7.18^{\mathrm{a}}$ & $59.14 \pm 5.61^{\mathrm{a}}$ & $51.43 \pm 7.74^{\mathrm{a}}$ & $60.14 \pm 10.7^{\mathrm{a}}$ \\
R (mV) & $1.10 \pm 0.27^{\mathrm{a}}$ & $1.20 \pm 0.25^{\mathrm{a}}$ & $1.61 \pm 0.18^{\mathrm{a}}$ & $1.04 \pm 0.84^{\mathrm{a}}$ & $1.39 \pm 0.49^{\mathrm{a}}$ \\
QT $(\mathrm{ms})$ & $189.0 \pm 8.6^{\mathrm{a}}$ & $216.7 \pm 26.0^{\mathrm{b}}$ & $208.9 \pm 32.2^{\mathrm{a}}$ & $184.9 \pm 14.5^{\mathrm{a}}$ & $188.7 \pm 23.7^{\mathrm{a}}$ \\
HR $(\mathrm{bpm})$ & $122.1 \pm 22.5^{\mathrm{a}}$ & $104.9 \pm 18.0^{\mathrm{a}}$ & $105.9 \pm 16.9^{\mathrm{a}}$ & $130.0 \pm 23.4^{\mathrm{a}}$ & $135.6 \pm 12.8^{\mathrm{b}}$ \\
Axis $\left({ }^{\circ}\right)$ & $73.86 \pm 11.48^{\mathrm{a}}$ & $72.86 \pm 15.99^{\mathrm{a}}$ & $67.86 \pm 13.75^{\mathrm{a}}$ & $40.57 \pm 68.05^{\mathrm{a}}$ & $63.43 \pm 15.91^{\mathrm{a}}$ \\
\hline
\end{tabular}

$\mathrm{Pms}=\mathrm{P}$ wave duration (milliseconds) $\mathrm{PmV}=\mathrm{P}$ wave amplitude (millivolt); $\mathrm{PRms}=\mathrm{PR}$ interval duration (milliseconds) $\mathrm{QRSms}=$ QRS complex duration (milliseconds); RmV = R wave amplitude (millivolt); QTms = QT interval duration (milliseconds); HRbpm $=$ heart rate beats/minute; Axis (degree) = electrical cardiac axis. Values (mean \pm standard deviation) with the same letters in the same row for each group (control, mild, moderate, severe and very severe) are not statistically different $(\mathrm{P}>0.05)$.

Source: Elaboration of the authors.

The analysis of wave amplitudes and electrocardiographic parameter. Table 3 shows the durations in DII according to reference values for dogs (TILLEY, 1992; WOLF; CAMACHO; SOUZA, 2000) showed that $85.71 \%(24 / 28)$ of percentage of electrocardiographic abnormalities in anemic dogs classified according to the severity the anemic dogs produced at least one altered severe groups.

Table 3. Percentage of electrocardiographic abnormalities in anemic dogs $(n=28)$ divided according to the severity of anemia in four groups of seven dogs (mild, moderate, severe and very severe) and caused by natural infection with Ehrlichia canis and Babesia canis.

\begin{tabular}{lcccc}
\hline \multicolumn{1}{c}{ ECG abnormalities } & Mild (\%) & Moderate (\%) & Severe (\%) & Very severe (\%) \\
\hline Increase in P-wave amplitude & 42.86 & 14.29 & 28.57 & 14.29 \\
Increase in P-wave duration & 28.57 & 28.57 & 42.86 & 100 \\
Increase in QRS duration & 28.57 & 28.57 & 14.29 & 42.86 \\
Increase in R-wave amplitude & 14.29 & 85.71 & 28.57 & 57.14 \\
Abnormalities in PR interval & 0 & 0 & 0 & 0 \\
Abnormalities in QT interval & 57.14 & 14.29 & 14.29 & 42.86 \\
ST segment depression & 0 & 42.86 & 14.29 & 0 \\
ST segment elevation & 0 & 0 & 14.29 & 0 \\
Increase in T-wave amplitude & 14.29 & 14.29 & 14.29 & 14.29 \\
RV axis deviation & 0 & 0 & 14.29 & 0 \\
Cardiac rhythm disturbance* & 0 & 0 & 0 & 14.29 \\
\hline
\end{tabular}

* Junctional Rhythm; ECG = Electrocardiographic; RV = right ventricular.

Source: Elaboration of the authors.

However, when compared to the control group, only the values of P-wave amplitudes in the group with severe anemia and the QT intervals in the group with mild anemia were significantly increased. There 
was an association between the degree of anemia and an increased $\mathrm{P}$ wave duration $(\mathrm{p}=0.003)$.

Only $10.71 \%(3 / 28)$ of the anemic dogs showed increased concentrations of troponin I, with two of these dogs having very severe anemia and one having severe anemia. There was a negative correlation between the level of hemoglobin and an increased troponin I concentration $(\mathrm{r}=-0,950$, $\mathrm{p}=0,05)$. However, there was no association between increased levels of troponin I and electrocardiographic parameters suggestive of myocardial hypoxia, such as ST-segment elevation (Figure 1) or T-wave changes (Figure 2).

Figure 1. Electrocardiographic recordings showing ST-segment depression in dogs with moderate (A) and severe (B) anemia. Lead DII, $50 \mathrm{~mm} / \mathrm{s}$, sensibility, $\mathrm{N}$.

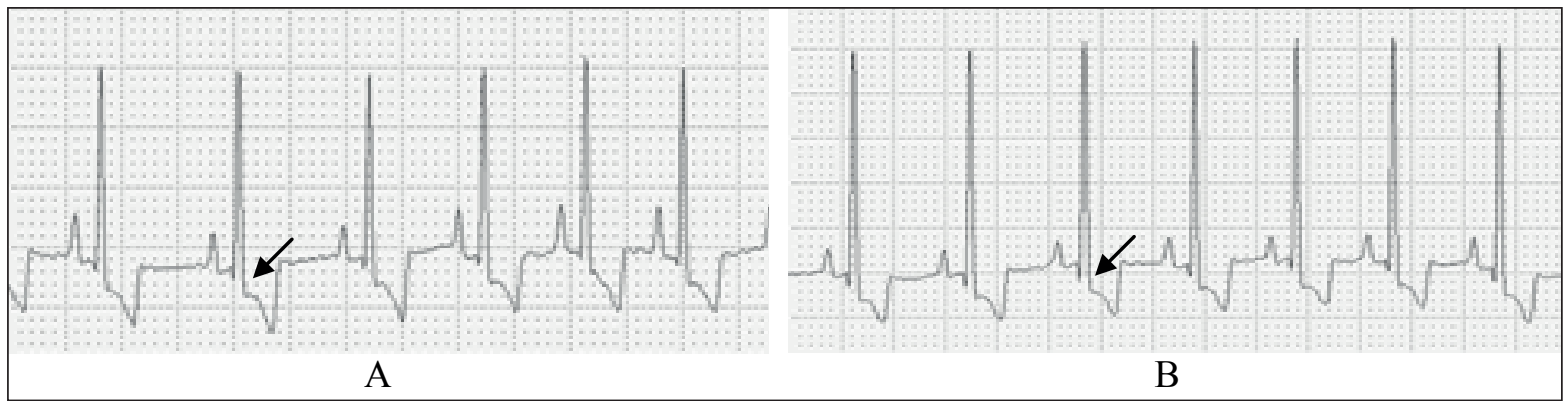

Source: Elaboration of the authors.

Figure 2. Electrocardiographic recordings showing increases in T-wave amplitude in dogs with mild (A), moderate (B), severe (C) and very severe (D) anemia. Lead DII, $50 \mathrm{~mm} / \mathrm{s}$, sensibility, N.

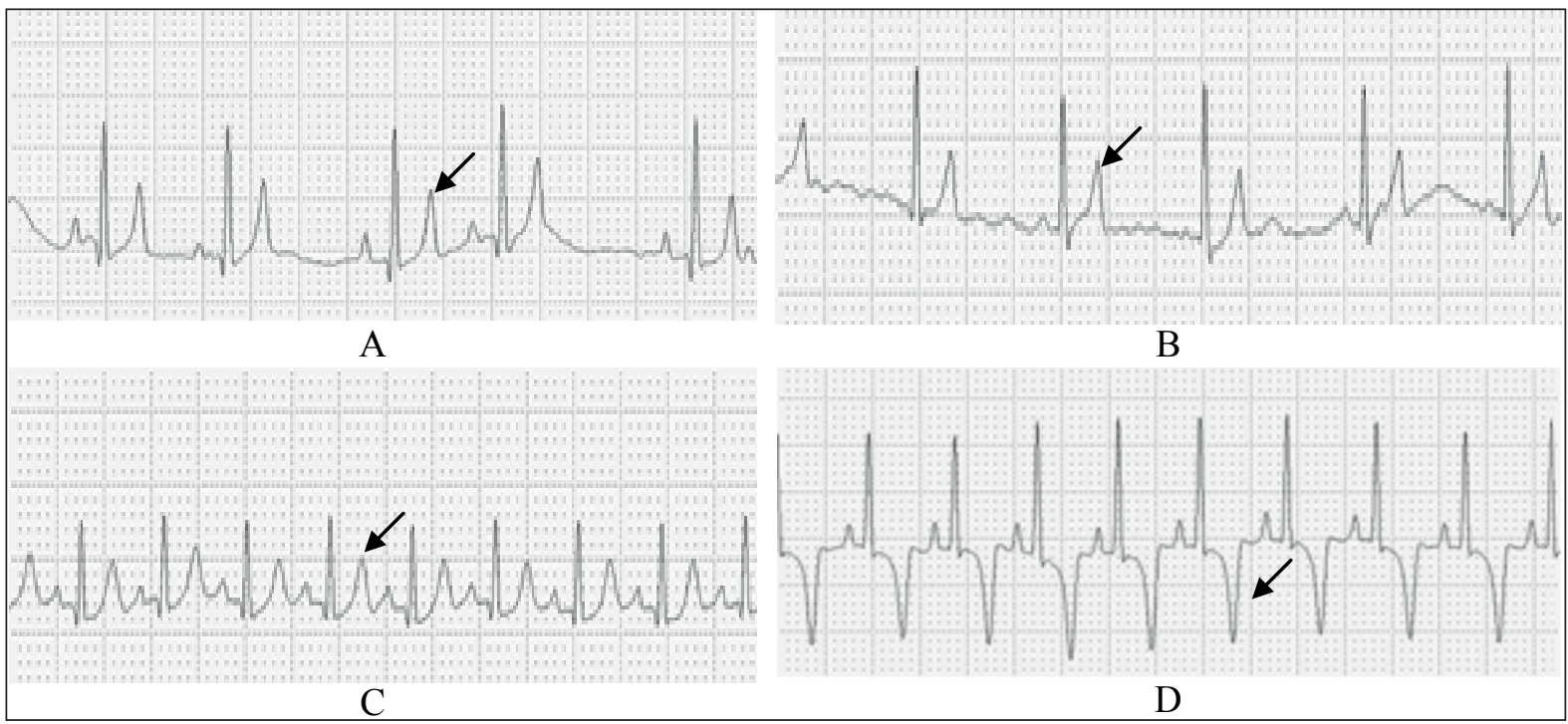

Source: Elaboration of the authors.

\section{Discussion}

Among the cardiac rhythms assessed by electrocardiography, sinus arrhythmia occurred most frequently $(85.71 \%)$ in dogs with mild and moderate anemia. In dogs with severe and very severe anemia, the occurrence of this rhythm was not as significant, likely due to the sympathetic activity surpassing the activities of the parasympathetic 
nervous system. In response to hypoxemia, it was observed that patients with anemia may have generalized peripheral vasodilation leading to hypotension, and as a compensatory mechanism, the vasodilation activates the sympathetic nervous system, allowing vasoconstriction to maintain a normal blood pressure range (MARTINS et al., 2012). Apart from vasoconstriction, sympathetic activation promotes an increased heart rate and positive inotropism (HORWICH et al. 2002; ANAND et al., 2004). In this study, there was no occurrence of sinus tachycardia; however, although the heart rate was within normal limits in all groups, the mean values of heart rates in dogs with very severe anemia were statistically higher than all the other dogs. The heart rate is increased in anemia due to hypoxia-stimulated chemoreceptors and increased sympathetic activity (METIVIER et al., 2000).

Electrocardiogram characteristics compatible with atrioventricular overload are perhaps related to an increased plasma volume, high levels of myocardial wall stress and left ventricular hypertrophy that occur in response to anemia because tissue hypoxia and peripheral vasodilation related to anemia lead to a hemodynamic response, such as sympathetic activation (METIVIER et al., 2000; MARTINS et al., 2012), activation of the renin angiotensin aldosterone system and increased production of the antidiuretic hormone (HORWICH et al., 2002; ANAND etal., 2004). These mechanisms promote water retention, which, when combined with myocardial hypoxia and oxidative stress, explain why anemia may precipitate congestive heart failure, even in normal individuals (ANAND et al., 2004).

In this study, left atrial enlargement was related to the degree of anemia severity, and all dogs with very severe anemia showed increases in the $\mathrm{P}$-wave duration. The same can be observed in relation to left ventricular overload because dogs with very severe anemia showed increases in the QRS complex more frequently $(48.86 \%)$ compared to other groups.
Because every animal included in this study had not heart disease, electrocardiographic findings consistent with atrial or ventricular overload may be related to compensatory hemodynamic changes. Furthermore, electrocardiographic traces that suggest left ventricular overload, such as changes in the QRS complex and the R wave, corroborate the findings on left ventricular hypertrophy previously described in dogs with anemia (SCHEEL; WILLIAMS, 1985).

Although only one dog had right ventricular electrical axis deviation, there was no consensus about the effects of anemia in the cardiac axis because there are reports of right axis deviation (MANOACH et al., 1971), left axis deviation (ROSENTHAL; RESTIEAUX; FEIG, 1971) and absence of ventricular axis deviation related to anemia (SINGH; SOOD, 1996).

The group of dogs with mild anemia showed a significant increase in the mean values of the QT interval; however, there is no clinical relevance because all values were within the reference values (TILLEY, 1992).

Abnormalities in the ST-segment (ST depression and elevation) were found in $17.86 \%$ of all anemic dogs, and only animals in groups with moderate and severe anemia showed these electrocardiographic abnormalities. It is presumed that this may be due to the preservation of tissue oxygenation and the absence of myocardial hypoxia in dogs with mild anemia because ST abnormalities are related to damage in ventricular repolarization. However, the absence of ST abnormalities in dogs with very severe anemia does not rule out the possibility of impaired myocardial perfusion and oxygenation because in this group, an alteration in the T-wave amplitude occurred, which also indicates impaired repolarization (TILLEY, 1992), and some dogs showed increases in troponin I concentrations, indicating myocardial damage (LINDE, et al., 2006).Currently, measurements using cardiac biomarkers have been used to assess the degree 
of cardiac injuries, and troponin I is considered to be a biomarker with high sensitivity (O'BRIEN; LANDT; LADENSON, 1997). Cardiac troponin I is located exclusively in the myocardium where it is the only existing form, and its sensitivity and specificity for acute myocardial infarction are 97\% and $95 \%$, respectively (LINDE et al., 2006). The increase in cardiac troponin I levels, especially in dogs with advanced degrees of anemia, may indicate the possibility of cardiac injury both by hypoxia and myocarditis, as described in dogs with myocarditis and hemoparasitosis (LOBETTI; DVIR; PEARSON, 2002; SHAH; MCGOWAN, 2003; DINIZ et al., 2008).

The cardiac injury associated with anemia results from a reduction in red cell mass because erythrocytes provide oxygen to myocardial cells and promote the exchange of antioxidants that prevent oxidative stress and programmed cell death (SZACHNIEWICZ et al., 2003). Dogs with other etiologies for anemia showed higher levels of cardiac troponin I (GOW et al., 2011). Moreover, with an increase in sympathetic activation, the time of diastole is reduced, and this may impair coronary perfusion and increased myocardial oxygen consumption (CRUVINEL; CASTRO, 2003).

In the study, the association between the levels of troponin I and anemia were verified, showing the possibility of cardiac lesions related to anemia. Ralli, Horwich and Fonarow (2005) indicated that anemia is a factor for increased mortality by heart failure in humans, and they found increased levels of troponin I in $50.9 \%$ of the anemic patients. This should be verified in dogs with cardiomyopathy.

The study has some limitations, such as the evaluation of 28 patients divided into four groups of seven dogs only. Other limitations are related to atrial and ventricular measurements of enlargement, since the electrocardiogram is not the gold standard exam for measuring cardiac chambers. Therefore, thoracic radiography and doppler echocardiography could increase the values of the results of this study. The laboratory tests that could be performed are PCR to confirm the diagnosis of blood parasitosis and the electrolytic evaluation to exclude its influence on electrocardiographic parameters as ST segment and $\mathrm{T}$ wave. Despite these limitations, the results of this study are relevant and further investigations can be performed to confirm the influences of hypoxia related to anemia on cardiovascular parameters in dogs, in several experimental models, since anemia is a very common medical condition in small animals.

\section{Conclusions}

Dogs with anemia may develop electrocardiographic changes consistent with sympathetic activation, such as increased heart rate and a decreased prevalence of respiratory sinus arrhythmia. Electrocardiographic changes suggestive of atrial enlargement, such as increased duration and amplitude of the $\mathrm{P}$ wave, are likely related to increased preload and cardiac remodeling. Despite changes in repolarization suggestive of myocardial hypoxia, as the amplitude of the $\mathrm{T}$ wave increased, an elevation in the ST segment was not very frequently found in this study. However, there were increases in the levels of troponin I in $10.71 \%$ of the dogs. It is noteworthy that there was an association between increased troponin I and the level of severity of anemia, showing a risk of cardiac damage in anemic dogs.

\section{Acknowledgement}

The authors acknowledge São Paulo Research Foundation (FAPESP) for the financial support (Proc. $\left.\mathrm{n}^{\circ} 06 / 50150-5\right)$ and Professor Rosangela Zacarias Machado from the Imunoparasitology Laboratory - UNESP - Jaboticabal for the serological exams.

This study was approved by the Institutional 
Animal Care Committee (protocol number 004143/11).

\section{References}

AIRD, B. Clinical and hematologic manifestation of anemia. In: FELDMAN, B. F.; ZINKL, J. G.; JAIN, N. C. (Ed.). Schalm's veterinary hematology. $5^{\text {th }}$ ed. Philadelphia: Williams \& Wilkins, 2000. p. 140-150.

ANAND, I.; MCMURRAY, J. J. V.; WHITMORE, J.; WARREN, W.; MCCAMISH, M. A.; BURTON P. B. J. Anemia and its relationship to clinical outcome in heart failure. Circulation, Dallas, v. 110, n. 2, p. 149-154, 2004.

CHAMPION, T.; PEREIRA NETO, G. B.; CAMACHO, A. A. Effects of Acute normovolemic anemia on hemodynamic parameters and acid-base balance in dogs. Veterinary Medicine International, New York, v. 2011, p. 1-6, 2011.

CRUVINEL M. G. C.; CASTRO, C. H. V. Disfunção diastólica: sua importância para o anestesiologista. Revista Brasileira de Anestesiologia, Rio de Janeiro, v. 53, n. 2, p. 237-247, 2003.

DINIZ, P. P. V. P.; DE MORAIS, H. S. A.; BREITSCHWERDT, E. B.; SCHWARTZ, D. S. Serum cardiac troponin I concentration in dogs with ehrlichiosis. Journal of Veterinary Internal Medicine, Philadelphia, v. 22, n. 5, p. 1136-1143, 2008.

GOW, D. J.; GOW, A. G.; BELL, R.; SPRATT, D.; CASH, R.; RICKETTS, S.; ARCHER, J.; MELLANBY, R. J. Serum cardiac troponin I in dogs with primary immune-mediated haemolytic anaemia. Journal of Small Animal Practice, Oxford, v. 52, n. 5, p. 259-64, 2011.

HORWICH, T.; FONAROW, G. C.; HAMILTON, M. A.; MACLELLAN, W. R.; BORENSTEIN, J. Anemia is associated with worse symptoms, greater impairment in functional capacity and a significant increase in mortality in patients with advanced heart failure. Journal of American College of Cardiology, New York, v. 39, n. 11, p. 1780-1786, 2002.

JONES, T. C.; HUNT, R. D.; KING, N. W. Patologia veterinária. 6. ed. São Paulo: Manole, 2000. 1415 p.

KOMAJDA, M. Prevalence of anemia in patients with chronic heart failure and their clinical characteristics. Journal of Cardiac Failure, Naperville, v. 10, n. 1, p. S1S4, 2004.

LINDE, A.; SUMMERFIELD, N. J.; SLEEPER, M. M.; WRIGHT, F. B.; CLIFFORD, C. A.; MELGAREJO, T.; KNIGHT, D. H. Pilot study on cardiac troponin I levels in dogs with pericardial effusion. Journal of Veterinary Cardiology, Bern, v. 8, n. 1, p. 19-23, 2006.

LOBETTI, R. G. Cardiac involvement in canine babesiosis. Journal of the South African Veterinary Association, Pretoria, v. 76, n. 1, p. 4, 2005.

LOBETTI, R.; DVIR, E.; PEARSON, J. Cardiac troponins in canine babesiosis. Journal of Veterinary Internal Medicine, Philadelphia, v. 16, n. 1, p. 63-68, 2002.

MANOACH, M.; GITTER, S.; GROSSMAN, E.; VARON, D.; GASSNE, S. Influence of hemorrhage on the QRS complex of the electrocardiogram. American Heart Journal, St. Louis, v. 82, n. 1, p. 55-61, 1971.

MARTINS, W. D. A.; LOPES, H. F.; CONSOLIMCOLOMBO, F. M.; GUALANDRO, S. D. F. M.; ARTEAGA-FERNÁNDEZ, E.; MADY, C. Cardiovascular autonomic dysfunction in sickle cell anemia. Autonomic Neuroscience, New York, v. 166, n. 1, p. 54-59, 2012.

METIVIER, F.; MARCHAIS, S. J.; GUERIN, A. P.; PANNIER, B.; LONDON, G. M. Pathophysiology of anaemia: focus on the heart and blood vessels. Nephrology Dialysis Transplantation, Oxford, v. 15, p. 14-18, 2000. Supplement 3.

O'BRIEN, P. J.; LANDT, Y.; LADENSON, J. H. Differential reactivity of cardiac and skeletal muscle from various species in a cardiac troponin I immunoassay. Clinical Chemistry, New York, v. 43, n. 12, p. 23332338, 1997.

PORTMAN, M. A.; STANDAERT, T. A.; NING, $\mathrm{X}$. Relation of myocardial oxygen consumption and function to high energy phosphate utilization during graded hypoxia and reoxygenation in sheep in vivo. Journal of Clinical Investigation, New York, v. 95, n. 5, p. 2134, 1995.

RALLI, S.; HORWICH, T. B.; FONAROW, G. C. Relationship between anemia, cardiac troponin I, and B-type natriuretic peptide levels and mortality in patients with advanced heart failure. American Heart Journal. St. Louis, v. 150, n. 6, p. 1220-1227, 2005.

ROSENTHAL, A.; RESTIEAUX, N. J.; FEIG, S. A. Influence of acute variations in hematocrit on the QRS complex of the Frank electrocardiogram. Circulation, Dallas, v. 44, n. 3, p. 456-465, 1971.

SCHEEL, K. W.; WILLIAMS, S. E. Hypertrophy and coronary and collateral vascularity in dogs with severe chronic anemia. American Journal of Physiology:Heart and Circulatory Physiology, Bethesda, v. 249, n. 5, p. H1031-H1037, 1985. 
SHAH, S. S.; MCGOWAN, J. P. Rickettsial, ehrlichial and Bartonella infections of the myocardium and pericardium. Frontiers in Bioscience, Tampa, v. 8, n. 1. p. e197, 2003.

SINGH, K.; SOOD, S. Mean electrical axis of heart in chronic severe anemia. Indian Journal of Medical Sciences, Bombay, v. 50, n. 10, p. 359, 1996.

SZACHNIEWICZ, J.; PETRUK-KOWALCZYK, J.; MAJDA, J.; KACZMAREK, A.; RECZUCH, K.; KALRA, P. R.; PIEPOLI, M. F.; ANKER, S. D.; BANASIAK, W.; PONIKOWSKI, P. Anaemia is an independent predictor of poor outcome in patients with chronic heart failure. International Journal of Cardiology, Amsterdam, v. 90, n. 2, p. 303-308, 2003.

TILLEY, L. P. Essentials of canine and feline electrocardiography. $3^{\text {rd }}$ ed. Philadelphia: Lea \& Febiger, 1992. $470 \mathrm{p}$.

WOLF, R.; CAMACHO, A. A.; SOUZA, R. C. Eletrocardiografia computadorizada em cäes; Computerized electrocardiography in dogs. Arquivo Brasileiro de Medicina Veterinária e Zootecnia, Belo Horizonte, v. 52, n. 6, p. 610-5, 2000. 